\title{
Soft Tissue Sarcoma cM0 TNM Finding v7
}

National Cancer Institute

\section{Source}

National Cancer Institute. Soft Tissue Sarcoma CMO TNM Finding v7. NCI Thesaurus.

Code C88468.

Soft tissue sarcoma without evidence of distant metastasis. (from AJCC 7th Ed.) 